\title{
COMMENT: LIBERTY, PROSPERITY, AND A STRONG JUDICIAL INSTITUTION
}

\author{
Stephen G. BREyER*
}

I

The members of our Court at times have the experience of talking to judges and lawyers from other countries, particularly from $L$ atin A merica and E astern E urope. What we discover, across the board, I can only describe as the movement, almost worldwide, toward a realization that people's liberty and their prosperity depend in part upon strong judicial institutions.

R ecently, I heard A lan G reenspan, Chairman of the Federal R eserve, discuss the link between prosperity and a vibrant judiciary. He spoke of how business throughout the world requires courts that work fairly, honestly, and efficiently. People in all areas of society have begun to realize that strong courts are necessary for prosperity. By being able to see, through television and what they read in the newspapers, what happens in other countries, they have also come to realize that the same is true for personal liberty. So we in the judiciary understand, and I believe the A merican people understand, that what they treasure, their liberty, and also their prosperity, depends upon strong judicial institutions.

We as lawyers and judges also believe something that is sometimes harder for a person who is not a lawyer or a judge to understand-that strong judicial institutions depend upon judicial independence. What we mean by judicial independence is an assurance that the judge will never respond to what used to happen in some countries: the telephone call from the party boss in the middle of the night- "telephone justice" - telling the judge how to decide the case.

The assurance of judicial independence has many features. It depends in part upon a length of service not subject to the will of a political official. There must be some security that salaries will not be diminished simply because a judge makes an unpopular decision. Judges must have adequate resources to do their jobs. Judicial independence also necessitates that judges' decisions be totally open to criticism by the press, by legislators, and by the public. There must be an assurance that the judge is honest; this involves frequent public

\footnotetext{
Copyright @ 1998 by L aw and Contemporary Problems

This comment is also available at http://www.law.duke.edu/journals/61L CPB reyer.

* A ssociate J ustice, Supreme Court of the U nited States.

This comment is adapted from J ustice B reyer's remarks at a conference entitled Bulwarks of the Republic: J udicial Independence and A ccountability in the A merican System of J ustice, held in Philadelphia in D ecember 1998. The remarks were directed primarily to federal and state judges.
} 
scrutiny of the judge's financial affairs. It may make us uncomfortable to file the disclosure forms, but it is necessary.

Judicial independence also means that a judicial institution is functioning fairly, honestly, and effectively at a cost that people can afford; after all, the courts are simply a means to an end. We must keep in mind that judicial independence is a means toward a strong judicial institution. The strong judicial institution is a means toward securing the basic goals of people: human liberty and a reasonable level of prosperity.

L egislative control of the judiciary's funding is only one difficult aspect of the issue of judicial independence. Legislators adopt the statutes creating the judiciary and they appropriate its budget; in addition, of course, the laws enacted by the legislature are continuously interpreted by judges. It is not surprising, then, that legislators sometimes ask, "W hy do you judges ask me to vote the money for your institution but not try to exercise any control over that institution?" The judges respond, "Because that is what judicial independence means." The relationship between legitimate oversight and illegitimate control, however, is a little more complex than that. It is a difficult task to define the limits that govern the relationship between the legislator and the judge in a system of government that simultaneously requires democratic accountability and judicial independence. ${ }^{1}$

\section{II}

The notion of judicial independence is also a state of mind-on the part of the judge, the legislator, and the public. What do I mean by that? A R ussian paratroop general was visiting our Court, and the State and D efense Departments were particularly anxious that he have a successful visit: In his previous capacity, he had been in charge of missiles that once targeted the U nited States but which no longer do. I was talking to him and took him around the Court. $\mathrm{H}$ e asked what I thought was the most important decision in the last one hundred years. In my opinion, it was B rown v. B oard of E ducation, ${ }^{2}$ which dismantled segregation in the South. B ut I added, with some forethought, not to forget a decision called Cooper v. A aron. ${ }^{3}$ In that case, all nine J ustices signed an opinion ordering that black children who wanted to attend a white school in the city of Little R ock - but were prevented by the governor and the state militia"They will go in," said the nine J ustices. Well, the J ustices were only nine human beings. Neither nine hundred nor nine thousand judges by themselves could have successfully seen that the children entered the school. The critical fact was that the President of the $U$ nited States sent the paratroopers. M y message to the paratroop general was that the paratroopers and the judges must

1. See Ernest A. Finney, J r., Comment, 61 LA W \& ConTEMP. Probs. 55 (Summer 1998); Peter $M$. Shane, Interbranch A ccountability in State G overnment and the Constitutional R equirement of J udicial Independence, 61 LA W \& CONTEMP. PROBS. 21 (Summer 1998).

2. 347 U .S. 483 (1954).

3. 358 U .S. 1 (1958). 
cooperate. Why is that? I cannot answer it in terms of words on paper. The answer includes more than the words in our Constitution. It also includes 200 years of history and a civil war, eighty years of experience with a segregated South, and other events that led to an expectation of public behavior that led the President to send those paratroopers. That is what we have inherited.

The principle of Cooper v. A aron may be a part, maybe only a small part, of judicial independence. But judicial independence is a matter of expectation, habit, and belief among not just judges, lawyers, and legislators, but millions of other citizens. O ur institutions rest on what those hundreds of millions of citizens think.

Judicial independence, therefore, is ultimately a question of helping the public to understand. To understand what? N ot simply why the public should follow unpopular judicial decisions with which I agree, but also why the public should follow unpopular decisions with which I disagree. I must be able to explain to the public why we all should support judicial independence in the face of decisions that both you and I believe are wrong. What is the explanation? The answer has to be put in terms of liberty and prosperity, and it has to be consistent with a democratic society.

I think that judges themselves find it difficult to produce an explanation that in fact convinces the public. Why is that? It is not because judicial independence is unimportant-it is very important. $R$ ather, it is because as soon as I start talking about the need for tenure, security for salaries, and adequate resources, the average person will say, "O f course you think that, you have a personal interest, you are a judge, those are your problems. Every person has problems, and many have worse problems than you." If the need for judicial independence is to be explained convincingly-given that we who have the obvious institutional self-interest have trouble delivering the message- I think it is up to others to do much of the explaining. If the Bar, without the same selfinterest, understands that need and explains it, then I think the message might get across. 